\title{
Model Hands on Mathematics (HoM) Berbantuan LKPD Bernuansa Islami Materi Garis dan Sudut
}

\author{
Wiwik Sulistiana Dewi ${ }^{*}$, Nanang Supriadi ${ }^{1}$, Fredi Ganda Putra ${ }^{1}$ \\ ${ }^{1}$ Universitas Islam Negeri Raden Intan Lampung. Jalan Endro Suratmin, Sukarame, \\ Bandar Lampung 35133, Indonesia. \\ *Corresponding Author. E-mail: Wiwiksulistiana558@gmail.com
}

Received : 14-11-2017; Revised : 05-01-2018; Accepted : 29-01-2018

\begin{abstract}
Abstrak
Penelitian ini bertujuan untuk mengetahui apakah terdapat pengaruh model pembelajaran Hands On Mathematics berbantuan lembar kerja peserta didik (LKPD) yang terintegrasi pada nilai-nilai keislaman terhadap kemampuan berpikir kritis matematis pada pokok bahasan garis dan sudut. Metode penelitian yang digunakan merupakan penelitian eksperimen. Jenis penelitiannya adalah penelitian Quasy Experimental Design. Instrumen yang digunakan adalah tes kemampuan berpikir kritis pada materi pembelajaran garis dan sudut. Analisis data menggunakan uji anova satu jalan dengan sel sama. Kesimpulan dari penelitian ini adalah terdapat pengaruh model pembelajaran Hands On Mathematics berbantuan LKPD yang terintegrasi pada nilai-nilai keislaman terhadap kemampuan berpikir kritis matematis peserta didik yang lebih baik dibandingkan model pembelajaran yang lain.
\end{abstract}

Kata Kunci: HOM, LKPD, Keislaman, Berpikir Kritis

Abstract

This study aims to find out whether there is the influence of learning model of Hands-On Mathematics with the help of learner worksheet (LKPD) integrated on Islamic values to critical mathematical thinking ability on the subject line and angle. The research method used is experimental research. The type of research is Quasi-Experimental Design research. The instruments used are critical thinking skills tests online and angle learning materials. Data analysis using one-way ANOVA test with the same cell. The conclusion of this research is that there is the influence of learning model of Hands-On Mathematics with LKPD which is integrated on Islamic values to students' mathematical critical thinking ability better than another learning model.

Keywords: HOM, LKPD, Critical Thinking

\section{PENDAHULUAN}

Pendidikan merupakan salah satu hal penting dalam kehidupan, oleh karena itu di Indonesia terdapat beberapa cara yang dilakukan manusia untuk mendapatkan pendidikan, salah satunya adalah pendidikan formal. Pendidikan formal dapat ditemukan disekolah dengan berbagai pelajaran yang ada salah satunya adalah pelajaran matematika. Pelajaran matematika memiliki enam kemampuan yang wajib dimiliki oleh peserta didik dan salah satu kemampuan tersebut adalah kemampuan berpikir kritis matematis (Abdullah, 2016).
Kemampuan berpikir kritis dapat menjadikan manusia untuk lebih menganalisa terlebih dahulu suatu informasi yang baru didapat dan mencari tau sumber informasi, setelah itu mencari cara dalam penyelesaian masalah tersebut. Dalam sudut pandang lain berpikir kritis mutlak dimiliki oleh para peserta didik (Mujib, 2016). Pada proses kegiatan pembelajaran, berpikir kritis sangat diperlukan dalam menyelesaian berbagai permasalahan yang ada salah satu nya pada mata pelajaran matematika, dimana peserta didik tidak secara langsung mengambil kesimpulan 
terhadap suatu pernyataan, peserta didik terlebih dahulu menganalisis, mencari tahu kebenaran dari sumber tersebut baru kemudian menerapkan strategi yang tersusun dalam menyelesaikan masalah tersebut. Akan tetapi, peserta didik banyak yang belum bisa mengembangkan kemampuan berpikir kritis yang dimilikinya, hal tersebut dapat disebabkan oleh beberapa faktor, salah satu yang diduga mempengaruhi adalah proses kegiatan belajar mengajar di dalam kelas (Putra, 2016).

Menjadikan peserta didik lebih aktif dalam kegiatan pembelajaran adalah suatu aspek penting dalam proses pembelajaran, maka diperlukan suatu model pembelajaran yang melibatkan peserta didik terjun secara langsung. Model pembelajaran Hands On Mathematics adalah sentuhan tangan atau mengotak-ngatik obyek dengan tangan, benda-benda tiruan atau obyek konkrit yang secara sengaja disiapkan untuk lebih merangsang pikiran peserta didik (Wiguna, Marhaeni, \& Ardana, 2014). Benda-benda tiruan yang dipergunakan untuk peserta didik di dalam pembelajaran. Peserta didik yang diajarkan dengan menggunakan model pembelajaran kontekstual menghasilkan kemampuan pemecahan masalah yang lebih baik dari pada peserta didik yang diajarkan dengan menggunakan metode ceramah (Putra, 2017).

Saat ini salah satu tugas yang dimiliki guru yaitu memiliki perangkat pembelajaran sebelum proses kegiatan belajar mengajar dimulai. Untuk menciptakan suasana belajar menyenangkan, maka guru perlu merancang perencanaan pembelajaran, pemilihan pembelajaran yang bervariasi, media yang menarik, sehingga dalam kegiatan pembelajaran siswa memiliki peran aktif. Pemakaian bahan ajar bisa meningkatakan rasa penasaran siswa tinggi, menciptakan semangat baru, bahkan berdampak baik terhadap siswa
(A. U. Sari, Farida, \& Putra, 2017) secara lebih lanjut penggunaan media pembelajaran memberikan perasaan senang bagi peserta didik (Putra, 2017). Pengembangan media sangat penting artinya untuk meminimalisir kekurangan dan keterbatasan yang sudah ada (Sudarmi \& Muhar, 2015). Disisi lain, media yang untuk diri sendiri dapat mengurangi ketidak cocokan, sehingga sudah sama halnya dengan kebutuhan. Lembar kerja peserta didik merupakan salah satu media sarana untuk membantu guru dan siswa dalam kegiatan belajar mengajar. Penggunaan media berupa LKPD dapat membantu peserta didik dalam mengembangkan konsep, melatih peserta didik dalam menemukan dan mengembangkan keterampilan proses pembelajaran, serta membantu peserta didik memperoleh catatan tentang materi yang dipelajari melalui kegiatan belajar secara sistematis. Pembelajaran matematika dengan menggunakan model pembelajaran Hands On Mathematics berbantuan LKPD yang terintegrasi nilainilai keislaman diharapkan dapat membuat peserta didik lebih antusias dan dapat meningkatkan rasa ingin tahu yang tinggi. Berdasarkan beberapa masalah yang telah diutarakan sebelumnya, peneliti tertarik untuk mengadakan penelitian dengan judul Implementasi Model Hands On Mathematics berbantuan LKPD bernuansa Islami terhadap Kemampuan Berpikir Kritis Matematis.

\section{METODE}

Metode penelitian yang digunakan merupakan penelitian eksperimen. Jenis eksperimen yang digunakan adalah Quasy Experimental Design. Dalam pengumpulan data, peneliti menggunakan beberapa teknik yaitu observasi, peneliti melakukan pengamatan untuk mendapatkan informasi, teknik wawancara yaitu peneliti bertanya langsung kepada guru mata pelajaran mengenai kondisi kegiatan belajar mengajar dan kemampuan peserta didik, 
teknik dokumentasi peneliti mencari data dari sumber tertulis, teknik tes peneliti melakukan test kemampuan awal untuk mengetahui kemampuan berpikir kritis. Analisis data peneliti menggunakan anova satu jalan dengan sel sama. Uji prasyarat yang digunakan adalah adalah uji normalitas, homogenitas dan keseimbangan.

\section{HASIL DAN PEMBAHASAN}

Sesuai dengan rancangan penelitian yang telah dirumuskan sebelumnya, uji hipotesis untuk penelitian ini menggunakan uji anava satu jalan dengan sel sama. Uji anova satu jalan sel sama dilakukan setelah peneliti melakukan uji normalitas dan uji homogenitas. Dari hasil perhitungan, diperoleh bahwa masing-masing kelompok memiliki data yang normal dan kedua kelompok sampel memiliki varians yang homogen. Karena data telah normal dan homogen maka langkah selanjutnya adalah melakukan uji anova satu jalan dengan sel sama. berikut hasil kemampuan berpikir kritis peserta didik setelah diberikan perlakuan di masing-masing kelas, peneliti melakukan possteset pada akhir pembelajaran dengan menggunakan indikator-indikator kemampuan berpikir kritis peserta didik dan didapatkan hasil sebagai berikut:

Pembelajaran yang diterapkan pada kelas eksperimen pertama adalah pembelajaran dengan menggunakan model pembelajaran Hands On Mathematics, pada kelas eksperimen kedua adalah pembelajaran dengan menggunakan model pembelajaran Hands On Mathematics berbantuan LKPD yng terintegrasi nilai-nilai keIslaman, sedangkan pada kelas kontrol adalah pembelajaran yang biasa diterapkan oleh guru.

Untuk mengetahui apakah ketiga kelompok sampel (hands on mathematics berbantuan LKPD bernuansa Islami $\left(\mathrm{X}_{1}\right)$, hands on mathematics $\left(\mathrm{X}_{2}\right)$, Konvensional $\left(\mathrm{X}_{3}\right)$ yang terpilih berdistribusi normal atau tidak, maka dilakukan uji normalitas pada masing-masing kelompok yaitu kelas eksperimen pertama, kelas eksperimen kedua dan kelas kontrol. Hasil uji normalitas data kemampuan awal disajikan pada Tabel 1.

\section{Tabel 1. Hasil Uji Normalitas Terhadap Data Kemampuan Awal}

\begin{tabular}{cccc}
\hline $\mathrm{K}$ & Lhitung & Ltabel & Kesimpulan \\
$\mathrm{X}_{1}$ & 0.146 & 0.156 & Normal \\
$\mathrm{X}_{2}$ & 0.147 & 0.156 & Normal \\
$\mathrm{X}_{3}$ & 0.114 & 0.156 & Normal \\
\hline
\end{tabular}

Berdasarkan Tabel 1., kelompok belajar pada masing-masing kelas mempunyai nilai Lhitung $\leq$ Ltabel sehingga dapat disimpulakan data berasal dari sebaran normal. Hal ini berarti bahwa setiap kelompok sampel berasal dari populasi yang berdistribusi normal.

Setelah dilakukan uji normalitas kemudian dilanjutkan dengan uji homogenitas data amatan. Uji homogenitas varians pada penelitian ini menggunakan uji Bartlet karena digunakan pada penelitian lebih dari 2 kelompok data. Hasil uji homogenitas variansi populasi terhadap data kemampuan berpikir kritis peserta didik, diperoleh nilai $\chi^{2}$ hitung $=1.154 \leq \chi^{2}$ tabel $=$ 5.591. Hal ini berarti pada taraf signifikansi 0.05 , populasi-populasi yang dibandingkan, kelompok eksperimen satu, kelompok eksperimen dua, dan kelompok kontrol mempunyai variansi yang sama (homogen).

Sebelum peneliti melakukan eksperimen, peneliti melakukan uji keseimbangan terlebih dahulu. Uji keseimbangan yang peneliti gunakan adalah uji analisis variansi satu jalan dengan sel sama diperoleh $F_{\text {hitung }}=0.162$ dan $F_{\text {tabel }}=3.094$ dimana $F_{\text {hitung }}<F_{\text {tabel }}$, maka kesimpulannya adalah $\mathrm{H}_{0}$ diterima. Hal ini berarti bahwa kemampuan awal 
peserta didik yang akan mendapatkan penerapan model pembelajaran Hands On Mathematics, Hands On Mathematics berbantuan LKPD yang terintegrasi nilainilai keIslaman dan model pembelajaran Konvensional dalam keadaan seimbang.

Setelah pengujian pada data awal tersebut dilakukan, peneliti melanjutkan penelitian dengan menerapkan model pembelajaran pada masing-masing kelas. Kelas pertama menggunakan model pembelajaran Hands On Mathematics, kelas kedua menggunakan model pembelajaran Hands On Mathematics berbantuan LKPD yang terintegrasi nilai- nilai keIskaman dan kelas ketiga menggunakan model pembelajaran konvensional yaitu model pembelajara yang biasa diterapkan guru di sekolah.

Setelah peneliti menerapkan masingmasing model pembelajaran di masingmasing kelasnya, peneliti memberikan soal posttest yang memuat indikatorindikator kemampuan berpikir kritis peserta didik, dengan tujuan untuk perbedaan kemampuan berpikir kritis peserta didik sebelum dan sesudah penerapan model pembelajaran. Berikut ini adalah diagram rata-rata dari hasil posttest peserta didik dalam Gambar 1.

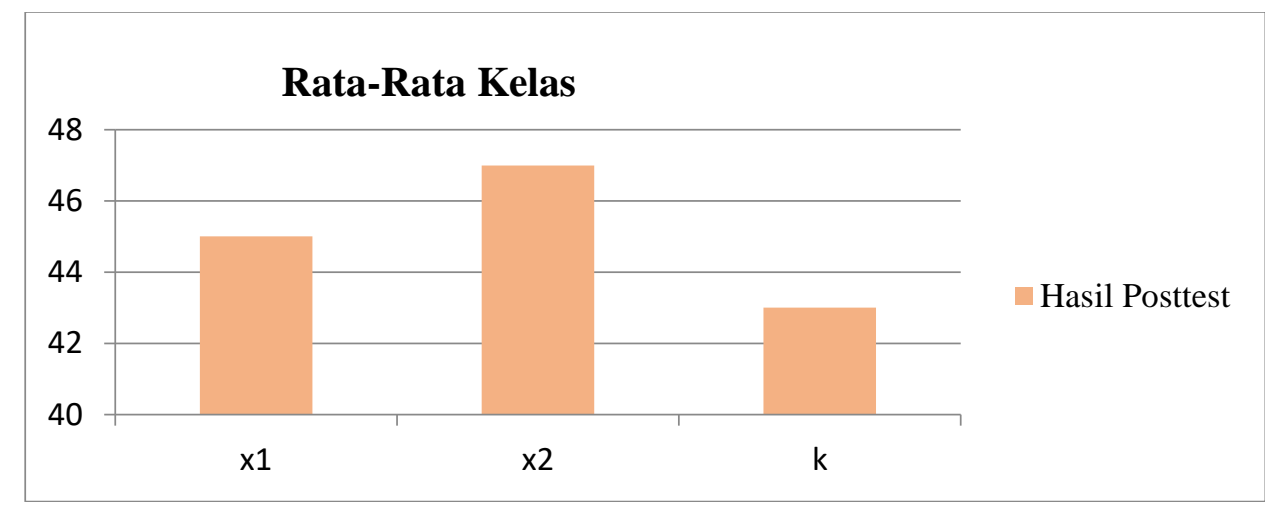

Gambar 1. Rata-rata Hasil Posttest Peserta Didik

Hasil tes kemampuan kemampuan berpikir kritis peserta didik tersebut kemudian dianalisis. Analisis pertama kali yang dilakukan yaitu uji normalitas dan homogenitas. Berdasarkan hasil analisis uji normalitas menunjukkan bahwa data kemampuan berpikir kritis dari kelas eksperimen pertama (Hands on Mathematics), kelas eksperimen kedua (Hands on Mathematics berbantuan LKPD bernuansa islami) dan kelas control (Konvensional) berasal dari populasi yang berdistribusi normal. Untuk uji homogenitas dari ketiga kelas sampel menunjukkan bahwa ketiga kelas mempunyai varians yang homogen. Analisis yang dilakukan berikutnya yaitu analisis untuk mengetahui apakah pembelajaran yang menerapkan model pembelajaran Hands On Mathematics berbantuan LKPD bernuansa Islami dapat memberikan pengaruh terhadap kemampuan berpikir kritis matematis pada peserta didik.

Berdasarkan hasil uji Anova satu jalan sel sama yang diperoleh, di dapatkan hasil yang ditunjukan pada Tabel 2. 
Desimal, 1 (1), 2018 - 61

Wiwik Sulistiana Dewi, Nanang Supriadi, Fredi Ganda Putra

Tabel 2. Hasil Uji Anava Satu Jalan Sel Sama

\begin{tabular}{cccccc}
\hline SK & JK & DB & KT & Fhitung & Ftabel \\
& & & & & \\
Model & 1532.33 & 2 & 766.16 & 13.84 & 3.09 \\
Galat & 5145.40 & 93 & 055.32 & & \\
Total & 6677.74 & 95 & 821.49 & & \\
\hline
\end{tabular}

Berdasarkan Tabel 2, diperoleh hasil berpikir kritis matematis. Rerata masingbahwa Fitung $>\mathrm{F}_{\text {tabel }}$ yang berarti $\mathrm{H}_{0}$ masing kelompok yang akan digunakan ditolak. Hal ini berarti bahwa terdapat pada uji lanjut anova ditunjukan pada pengaruh penerapan model pembelajaran Tabel 3.

Hands on Mathematic dengan LKP

bernuansa Islami terhadap kemampuan

Tabel 3. Rerataan Kelompok

\begin{tabular}{llc}
\hline No & \multicolumn{1}{c}{ Model Pembelajaran } & Rata-rata \\
1 & Hands On Mathematics $\left(\mu_{1}\right)$ & 74.337 \\
2 & Hands On Mathematics berbantuan LKPD bernuansa Islami $\left(\mu_{3}\right)$ & 75.852 \\
3 & Konvensional $\left(\mu_{2}\right)$ & 66.667 \\
\hline
\end{tabular}

Selanjutnya dilakukan uji komparasi ganda (Uji lanjut) dengan metode Scheffe, metode Scheffe digunakan dalam penelitian ini untuk mengetahui pasangan perlakuan mana yang memberikan pengaruh model mana yang lebih signifikan teradap kemampuan berpikir kritis peserta didik. Berikut adalah hasil uji komparani ganda (Uji lanjut) dirangkum pada Tabel 4 di bawah ini:

Tabel 4. Uji Scheffe

\begin{tabular}{cccc}
\hline Pasangan & F tabel & Fhitung & Keterangan \\
$\mu_{1}$ vs $\mu_{2}$ & 16.814 & & $\mathrm{H}_{0}$ ditolak \\
$\mu_{2}$ vs $\mu_{3}$ & 24.080 & \multirow{2}{*}{3.094} & $\mathrm{H}_{0}$ ditolak \\
$\mu_{1}$ vs $\mu_{3}$ & 0.651 & & $\mathrm{H}_{0}$ diterima \\
\hline
\end{tabular}

Berdasarkan Tabel 4., diperoleh hasil uji komparasi rerata antar baris pada masing-masing model pembelajaran dengan taraf signifikansi 0.05 diperoleh kesimpulan sebagai berikut:

Hipotesis yang pertama ( $\mu_{1}$ vs $\left.\mu_{2}\right)$, diperoleh bahwa $\mathrm{H}_{0}$ ditolak yang berarti terdapat perbedaan kemampuan berpikir kritis yang signifikan antara peserta didik yang mendapat model pembelajaran Hands On Mathematics dan model pembelajaran konvensional, rerata marginal kemampuan berpikir kritis peserta didik yang mendapat model pembelajaran Hands On Mathematics yakni 74.337 lebih besar dibandingkan rerata marginal kemampuan berpikir kritis peserta didik yang mendapat model pembelajaran konvensional, yakni 66.667. Dengan demikian, diperoleh kesimpulan bahwa kemampuan berpikir kritis peserta didik yang mendapatkan model pembelajaran Hands On Mathematics lebih baik dibandingkan kemampuan berpikir kritis peserta didik yang mendapatkan model pembelajaran konvensional. Pada proses pembelajaran, peserta didik yang memperoleh model pembelajaran Hands on Mathematics memang lebih aktif dibandingkan model pembelajaran konvensional yang terlihat monoton dalam belajar, sehingga diperoleh hasil bahwa penerapan model pembelajaran Hands on Mathematics lebih baik dibandingkan model pembelajaran konvensional. Hasil ini juga 
melengkapi penelitian yang telah lalu dengan hasil yang sama (Wiguna et al., 2014).

Hipotesis yang kedua ( $\mu_{2}$ vs $\mu_{3}$ ), diperoleh bahwa $\mathrm{H}_{0}$ ditolak yang berarti terdapat perbedaan kemampuan berpikir kritis yang signifikan antara siswa yang mendapat model Hands On Mathematics berbantuan LKPD bernuansa islami dan model pembelajaran konvensional, rerata marginal kemampuan berpikir kritis yang mendapat model pembelajaran Hands On Mathematics berbantuan LKPD bernuansa islami yakni 75.852 lebih besar dibandingkan rerata marginal kemampuan berpikir kritis peserta didik yang mendapat model pembelajaran konvensional, yakni 66.667. Dengan demikian, diperoleh simpulan bahwa kemampuan berpikir kritis peserta didik yang mendapat model pembelajaran Hands On Mathematics berbantuan LKPD yang terintegrasi nilai-nilai keIslaman lebih baik dibandingkan kemampuan berpikir kritis peserta didik yang mendapat model pembelajaran konvensional.

Hipotesis yang ketiga ( $\mu_{1}$ vs $\left.\mu_{3}\right)$, diperoleh bahwa $\mathrm{H}_{0}$ diterima yang berarti tidak terdapat perbedaan kemampuan berpikir kritis yang signifikan antara siswa yang mendapat model Hands On Mathematics dan model pembelajaran Hands On Mathematics berbantuan LKPD bernuansa islami. Dengan demikian, diperoleh simpulan bahwa kemampuan berpikir kritis peserta didik yang mendapat model pembelajaran Hands On Mathematics berbantuan LKPD bernuansa islami sama dengan kemampuan berpikir kritis peserta didik yang mendapat model pembelajaran Hands On Mathematics.

\section{SIMPULAN DAN SARAN}

Simpulan dalam penelitian ini adalah terdapat pengaruh model pembelajaran Hands on Mathematics bernilai Islami terhadap kemampuan berpikir kritis matematis peserta didik. Berdasarkan uji lanjut yang dilakukan diperoleh hasil bahwa: (1) model pembelajaran Hands On Mathematics menghasilkan kemampuan berpikir kritis yang lebih baik dibandingkan model pembelajaran konvensional; (2) model pembelajaran Hands On Mathematics bernuansa Islami menghasilkan kemampuan berpikir kritis yang lebih baik dibandingkan model pembelajaran konvensional; (3) Model pembelajaran Hands On Mathematics menghasilkan kemampuan berpikir kritis yang sama dengan model pembelajaran Hands On Mathematics bernuansa Islami. Berdasarkan simpulan tersebut, peneliti memberikan saran terhadap para pendidik agar lebih memberikan pembelajaran yang inovatif, dimana salah satunya adalah menggunakan model pembelajaran Hands on Mathematics.

\section{DAFTAR PUSTAKA}

Abdullah, I. H. (2016). Berpikir kritis matematik. Delta-Pi: Jurnal Matematika Dan Pendidikan Matematika, 2(1).

Mujib, M. (2016). Mengembangkan Kemampuan Berfikir Kritis Melalui Metode Pembelajaran Improve. AlJabar: Jurnal Pendidikan Matematika, 7(2), 167-180.

Putra, F. G. (2016). Pengaruh Model Pembelajaran Reflektif dengan Pendekatan Matematika Realistik Bernuansa Keislaman terhadap Kemampuan Komunikasi Matematis. Al-Jabar: Jurnal Pendidikan Matematika, 7(2), 203-210.

Putra, F. G. (2017). Eksperimentasi Pendekatan Kontekstual Berbantuan Hands On Activity (HoA) Terhadap Kemampuan Pemecahan Masalah Matematik. Al-Jabar: Jurnal Pendidikan Matematika, 8(1), 73-80. https://doi.org/10.24042/ajpm.v8i1 .1148

Sari, A. U., Farida, F., \& Putra, F. G. (2017). 
Desimal, 1 (1), 2018 - 63

Wiwik Sulistiana Dewi, Nanang Supriadi, Fredi Ganda Putra

Pengembangan Media Pembelajaran Berbantuan Web dengan Pendekatan Etnomatematika pada Pokok Bahasan Bangun Ruang Sisi Datar. Prosiding Seminar Nasional Matematika dan Pendidikan Matematika, 1(1), 209-214.

Sudarmi, D., \& Muhar, N. (2015). Pengaruh Penggunaan Media Gambar Kartun Terhadap Hasil Belajar Siswa Biologi pada Kelas VII MTsN Talaok Kecamatan Bayang
Kabupaten Pesisir Selatan. Abstract of Undergraduate, Faculty of Education, Bung Hatta University, $4(5)$.

Wiguna, I. G. L. A., Marhaeni, A. N., \& Ardana, I. M. (2014). Pengaruh Model Pembelajaran Berbasis Masalah Berbantuan Hands on Mathematics Terhadap Keaktifan dan Hasil Belajar Matematika Siswa Kelas V di SD. 1, 2, 5 Banyuasri. PENDASI: Jurnal Pendidikan Dasar Indonesia, 4(1). 